\title{
UNUSUAL CASE OF VESICO URETERAL REFLUX SECONDARY TO SINGLE RIGHT ECTOPIC URETER WITH BILATERAL FUNCTIONING KIDNEY
}

\author{
Vitthal Krishna1, R. D. Jaykar², Pradip Kasabe ${ }^{3}$, Sachin Jadhav ${ }^{4}$, Shivprasad Lakhpatre ${ }^{5}$
}

\section{HOW TO CITE THIS ARTICLE:}

Vitthal Krishna, R. D. Jaykar, PradipKasabe, SachinJadhav, ShivprasadLakhpatre."Unusual Case of Vesico Ureteral Reflux Secondary to Single Right Ectopic Ureter with Bilateral Functioning Kidney". Journal of Evolution of Medical and Dental Sciences 2014; Vol. 3, Issue 23, June 09; Page: 6575-6578,

DOI: $10.14260 /$ jemds/2014/2783

\begin{abstract}
Approximately half of woman with ectopic ureter present with a classical history of continuous dribbling incontinence depicts what appears to be a normal voiding pattern. An ectopic ureter may also be severely obstructed, causing massive hydronephrosis as an abdominal mass. We present a rare case of $40 \mathrm{yrs}$ old woman with a unilateral single ectopic ureter at bladder neck presented as repeated UTI and hydronephrosis but the patient was continent. We also have pleasure to present diagnostic and therapeutic process that often pose difficulties for many specialists including urologist, gynecologists, surgeons and radiologist.
\end{abstract}

KEYWORDS: Kidney-VUR- Ectopic ureteric orifice.

INTRODUCTION: Ectopic ureteric orifice is a rare congenital anomalous defect of urinary tract resulting from abnormal embryological development, where ureteral orifice is abnormally located and instead of draining in bladder, it drains in to urethra, vagina or in structures of mesonephric duct (ductus deference and seminal vesicles).

The Weigert-Meyer rule describes the inverse relationship of the duplex ureteral orifices, in which the ectopic ureter or ureterocele associated with the upper pole is caudal to the lower pole ureteral orifice. Typically it produces involuntary continuous leakage of urine from a ureter that is displaced beyond external sphincter this is called as enuresis ureterica. ${ }^{1}$

Epidemiologically ectopic ureter cases are found to be 1:2000 with more girls than boys. $80 \%$ of ectopic ureters are associated with a ureteral duplication. It drains in urethra (35\%), vulval vestibule (34\%), vagina (25\%) and uterus (5\%). ${ }^{2}$ Single-system ureteral ectopia differs from the more common double-system ectopia by a high incidence of associated malformations. Renal dysplasia is common, but does not bear a consistent relationship to the degree of ureteral ectopia.

However, in case of bilateral single ectopic ureters or in unilateral ectopic ureter associated with contralateral renal agenesis, subsequent malformation of the bladder trigone and bladder neck may result in additional voiding dysfunction.

The treatment of unilateral single system ectopia with a healthy contralateral kidney is simple and it consists of unilateral ureterovesical reimplantation. Cases with bilateral single-system ectopia or unilateral single-system ectopia with contralateral renal agenesis present difficult management. ${ }^{3}$

CASE REPORT: A 40 years old woman was admitted in surgery ward presenting with burning of micturition since 3-4 years. Laboratory tests showed normal renal function (Blood urea level, serum creatinine levels) and urine examination showed presence of 1-2 epithelial cells and 2-3 pus cells. No radio-opaque lesion was seen on KUB radiograph.Ultrasonography showed mild right sided hydronephrosis with proximal hydroureter. Intravenous urography showed grade 2-3 right sided 


\section{CASE REPORT}

hydronephrosis and hydroureter possibly secondary to VUR. MCU also shows right sided hydronephrosis and hydroureter. Cystoscopy showed an ectopic right ureteral orifice just below the bladder neck (Fig 1).

Patient was operated with ureteric reimplantation with "Lich Gregoir" technique.4 Postoperative course was uneventful and patient was discharged on postoperative day 14 .

Lich Gregoir Technique: It is an extravesical procedure for ureteral reimplantation originally described by Lich and colleagues (1961) in US and Gregoir in 1964 in Europe. In this technique, ureters are approached with pfannenstiel incision. Then creation of extravesical tunnel, approximation of detrusor for long submucosal tunnel and completion of repair. There is a Gil-Vernet laparoscopic extravesical procedure for ureteral reimplantation.

This technique has steep learning curve. Initial experiences describe challenges with exposure of ureter, trauma to ureter and difficulty developing the extra vesical tunnel without injuries to the urothelium in addition to long operative times. ${ }^{4}$

Other Causes of Vesicoureteral reflux with ureteral Abnormalities:

1. Complete ureteral duplication

2. Ureterocele

3. Uretero pelvic junction obstruction

4. Bladder diverticulum

Essential tenets ofreflux management:

1. Spontaneous resolution of reflux is very common

2. High grade reflux is less likely to resolve spontaneously

3. Sterile reflux is benign

4. Extended use of prophylactic antibiotics is benign

5. Success of (open) surgical correction is very high.

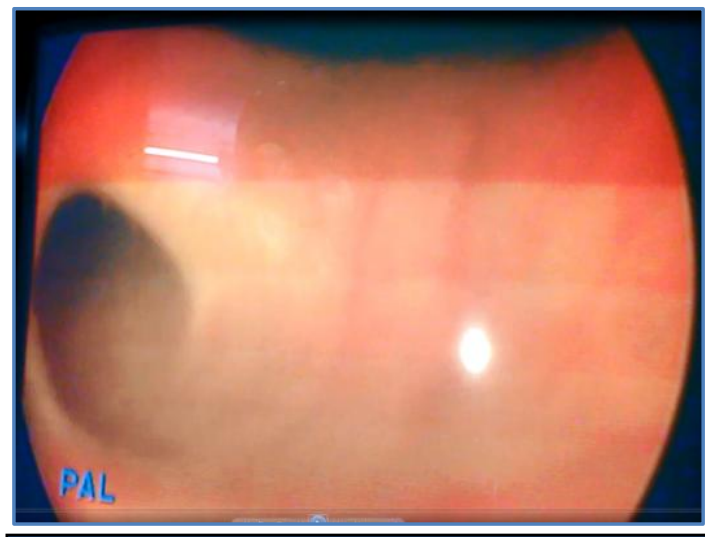

Fig. 1: Cystoscopy shows an ectopic right ureteral orifice at the bladder neck (arrow)

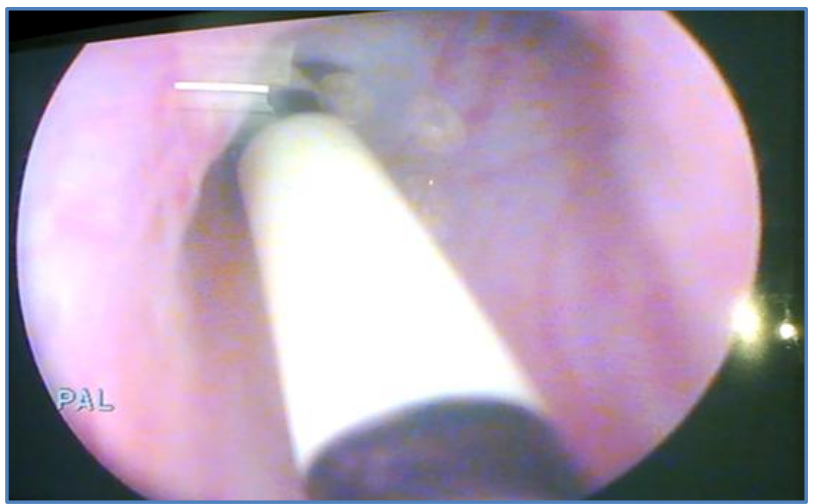

Fig 2: Ectopic ureter with ureteric catheter in it 


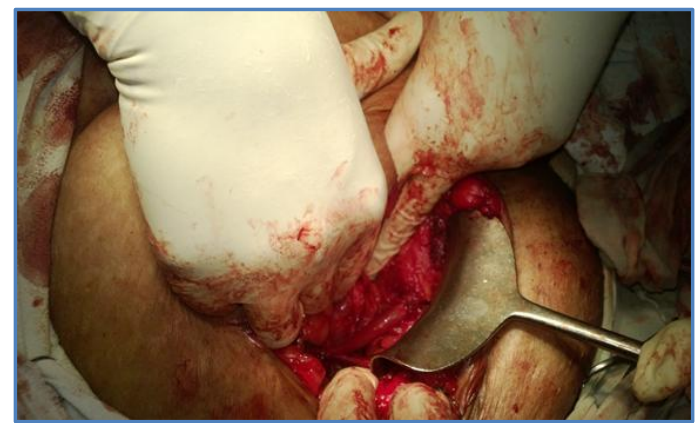

Fig. 3: Intraoperative picture showing ureter

DISCUSSION: By definition, an ectopic ureter is any ureter, single or duplex, that does not enter the trigonal area of the bladder. In a duplex system this is inevitably the upper pole ureter, presumably due to its budding from the mesonephric duct later than the lower pole ureteral bud. ${ }^{5}$

In females the ectopic ureter may enteranywhere from the bladder neck to the perineum i.e. into the vagina, uterus and even rectum. In males the ectopic ureter always enters the urogenital system above the external sphincter or pelvic floor and usually into the wolffian structures including vas deferens, seminal vesicles or ejaculatory duct. ${ }^{6}$

Either single or duplex systems with an ectopic ureter may present with severe hydronephrosis reflecting distal obstruction. Congenital urinary tract defects in adults cause many diagnostic difficulties. Ectopic ureter orifice, which produces enuresis ureterica is a relatively rare congenital defect, detected and treated mainly in children. ${ }^{7}$

Ectopia of ureteral orifice is often associated with dysplasia of the kidney or that portion of kidney drained by ectopic ureter. As a rule more ectopic the orifice the worse will be the dysplasia. Ectopic ureter orifice, which produces enuresis ureterica is a relatively rare congenital defect, detected and treated mainly in children. Its diagnosis is based on detailed clinical history and imaging examinations. The defect may be signaled by disordered urination and continuously wet diapers and underwear in older children. ${ }^{5}$

This is the main reason that causes parents to bring them to the doctor. The absence of continuous leakage of urine does not exclude the defect since the "upper" kidney is likely to be vestigial and produce small amounts of urine. Intravenous pyelography is a basic imaging technique, especially its late pictures that visualize deficient excretory function of the segment with the ectopic ureter. It is difficult to interpret the urographic picture as the "upper" segment minimally changes the direction of the long axis of the kidney, hence detecting the defect based on that examination is not easy, even for an experienced urologists. Other useful imaging techniques are USG and or a nuclear scan with $99 \mathrm{~m}$ Technetium. ${ }^{8}$

If the defect is undetected in early childhood, its diagnosis is even more difficult in adulthood. In adult women, especially after delivery, urinary incontinence should be differentiated from incontinence developed due to functional-anatomical disorders or other diseases such as genitourinary fistulas. Enuresis ureterica may recur after delivery due to mechanical removal of an obstruction from the ureter's orifice into the vagina. ${ }^{9}$

Then surgical treatment of an ectopic ureter in a female depends on the associated renal function. Single-system ureteral ectopia to the genital system usually has poor function, and a 
nephroureterectomy is appropriate when the other kidney has a good function. With single-system ectopia to the bladder neck or urethra, adequate kidney function on ectopic side may justify re implantation of the ureter into the bladder. ${ }^{10}$

\section{REFERENCES:}

1. MackieGG, Stephens FD Duplex kidneys: a correlation of renal dysplasia with position of the ureteral orifice. J Urol 1975; 114: 274-280

2. Zieliński J: Wadywrodzonenerek i drógmoczowych (Congenital abnormalities of the kidney and urinary tracts) In: Urologia Kliniczna, Zieliński J(ed), Warszawa: PZWL, Vol II, 1993; pp. 165169.

3. Ahmed S, Barker A. Single-system ectopic ureters: a review of 12 cases. J Pediatr Surg 1992; 27:491e6.

4. Campbell-Walsh Urology10th Edition International Edition Volume I 2012; 3219-3266.

5. Bakwin H: Enuresis in children. J Pediatr 1961; 58: 806-819.

6. Pattaras JG, Rushton $\mathrm{H}$, Majd M: The role of $99 \mathrm{~m}$ technetium dimercaptosuccinic acid renal scans in the evaluations of occult ectopic ureters in girls with paradoxical incontinence. J Urol 1999; 162: 821-825.

7. Thüroff J (ed): Diagnosty karóżnicowa w urologii (Differential diagnosis in urology). PZWL 1998; pp. 149-215.

8. Heuser M, Zoller G, Seseke F, Zappel H, Ringert RH. Bladder dysfunction in children with bilateral singleectopic ureters. J Pediatr Surg 2002; 37: E15.

9. Chowdhary SK, Lander A, Parashar K, Corkery JJ. Single system ectopic ureter: a 15-year review. Pediatr Surg Int 2001; 17: 638 e41.

10. Passerini Glazel G, Milani C, Bassi P, Chiozza L, Rizzoni G, Pagano F. Bilateral single ectopic ureter. Eur Urol 1988; 14.

\section{AUTHORS:}

1. Vitthal Krishna

2. R. D. Jaykar

3. PradipKasabe

4. Sachin Jadhav

5. Shivprasad Lakhpatre

\section{PARTICULARS OF CONTRIBUTORS}

1. Assistant Professor, Department of Uro Surgeon, Dr. V. M. Government Medical College, Solapur.

2. Associate Professor, Department of General Surgery, Dr. V. M. Government Medical College, Solapur.

3. Assistant Professor, Department of General Surgery, Dr. V. M. Government Medical College, Solapur.
4. Assistant Professor, Department of General Surgery, Dr. V. M. Government Medical College, Solapur

5. Resident, Department of General Surgery, Dr. V. M. Government Medical College, Solapur.

\section{NAME ADDRESS EMAIL ID OF THE CORRESPONDING AUTHOR:}

Dr. Shivprasad Lakhpatre,

Department of General Surgery,

$3^{\text {rd }}$ Floor,B Block,

Civil Hospital, Solapur-413003.

Email: shiv.sbl2010@gmail.com

Date of Submission: 24/04/2014.

Date of Peer Review: 25/04/2014.

Date of Acceptance: 20/05/2014.

Date of Publishing: 09/06/2014. 